\title{
Free for All: Foods, Landscapes, and Lives in the Paraguayan Chaco
}

Felice S. Wyndham ${ }^{1 *}$

${ }^{1} 290$ Stanton Way, Athens, GA, USA.

felice.wyndham@zoology.ox.ac.uk

\begin{abstract}
Foods and foodscapes structure and inform our experiences as ethnobiologists and ethnographers, the way we interact with and learn from teachers in study sites, and how relations between peoples and between people and landscapes unfold over time. This short memoir essay revisits my education in foodscapes with the Ayoreo community of Jesudi in the Paraguayan Chaco through stories and experiences of food procurement and distribution. From landscapes in which food was free for all (non-monetized) to contemporary encroachments and land-grabbing in the Chaco for globallyconnected markets, the transformations have been rapid and witnessed by Ayoreo and other dispossessed indigenous groups.
\end{abstract}

Received June 19, 2016

OPEN ӘACCESS

Accepted December 4, 2016

DOI 10.14237/ebl.7.2.2016.731

Keywords Ayoreo, Paraguayan Chaco, Wild foods, Landscape ethnobiology

Copyright (c) 2016 by the author(s); licensee Society of Ethnobiology. This is an open-access article distributed under the terms of the Creative Commons Attribution-NonCommercial 4.0 International Public License (https://creativecommons.org/licenses/by-nc/4.0), which permits non-commercial use, distribution, and reproduction in any medium, provided the original author and source are credited.

Siempre comemos juntos cuando ella recibe cosas ${ }^{1}$

—Queneja Dosapé, age 10

My first evening in Jesudi I was given a small strip of roasted giant anteater (Myrmecophaga tridactyla) for supper. It was very dark meat, slightly spicy, delicious, chewy, topped with a layer of creamy fat and burnt hide. Each person in the small Ayoreo community received a piece of the animal, and I, having been renamed Ichá (meaning 'newly arrived'), had also warranted a portion - a very small portion. To be included in the distribution changed me immediately.

It was 1998. I was a first-year ecological anthropology grad student from the US and I was in a small Ayoreo settlement in the Central Chaco of Northern Paraguay. Jesudi, a collective name for the esó fruit trees (Sideroxylon obtusifolium) that used to ripen there, was home to a group of families who had decided to move away from the Mennonite cooperatives and missionary camps about a decade earlier. They were trying to make it on their own as a community with more access to forest resources than they had in the camps, but without the benefits of either their traditional mobility across the landscape, or proximity to a town. I was there to complete a study of children's plant knowledge, but in many ways I ended up most transfixed by the more general context for that knowledge-how people interact with their landscapes, and with each other, through food and through storytelling. This essay addresses a few of these interconnections of personal histories, ethnobiology, and foodscapes during my first visit in 1998, and during subsequent trips in 2011, 2012, and 2014.

Jesudi was the first Ayoreo community living among the cojnone (whites) to be formed independently of the New Tribes Mission, any of the Catholic or Anglican missions, or Mennonite-organized labor settlements. In 1998 there were about eight extended families living there, from several Ayoreo sub-groups, who had lived in various mission camps-most commonly Campo Loro (New Tribes) and María Auxiliadora (Salesian)-following their particular experience of contact with cojnone in the 1960s-80s. The settlement is about 70 kilometers north of the Mennonite town of Filadelfia, on a dirt road that leads, after another few hundred kilometers northeast, to the riverine, palm-savannah, forests, and grasslands where many of the people in Jesudi grew up and consider their ancestral homelands near the Bolivian and Brazilian borders. There is little water in Jesudi, and it is a much drier thornscrub ecosystem than its residents were used to in their childhoods and young adulthoods living as hunters, gatherers, fishers, and gardeners further north. But the original settler 
families of Jesudi, after struggling to obtain legal land title from the Paraguayan government, were determined to make it work, and by and large they have.

In this essay I begin to explore the implications of understanding the work we do as ethnoecologists as a meeting ground, in the sense of Ermine's ethical space (2007:195), in which we can learn to see one another's knowledge systems as well as the spacesor thought-distances-between them. Especially in ethnobiology, an eye-level meeting of the minds is necessary to learn specifics, understand systems of knowledge, and relate to our interlocutors as teachers and hosts. The process is intensely relational, a dipping into experiences that are invited, moderated, and guided by the people we learn from. At the same time we need to learn the forms and spaces of the socio-political and worldview differences between us and those with whom we study, and between them and their wider local context. In the day-to-day, food is often the medium for communicating both the facts and the intentions of underlying relations, visible and invisible.

Stories about food intersect with memories of the past strongly for Ayoreo people, often evoking a narration or a story that illustrates their notion of place in the landscape, their historicizing of personal experiences of the colonial encounter, or their own identity and social relations (Besirre 2014; Blaser 2010; Glauser 2011:33). Over and over again in world ethnographies by outsider researchers, we read of the generosity of inclusion on the part of local communities and outsiders' attempts to learn from it. For me, being included in the roasted anteater meat distribution in Jesudi was a deeply appreciated invitation to relationship, and it awakened in me acute awareness of a dormant social faculty, that invisible web of reciprocity called The Gift by writers since Mauss (1990 [1950]).

The day before I arrived in Jesudi, I spent a couple of hours at the Mennonite cooperative supermarket in the town of Filadelfia, which, an hour and a half by car from Jesudi, was the nearest large store. I bought enough food to last weeks, I hoped. I knew from my reading that Ayoreo people especially prized honey, so I purchased a two liter jar of it, chuckling a bit at my extravagance, because such a quantity would last me years at home. The supermarket was delightfully cool and nicely organized, with long straight aisles of packaged foods and butcher, bread, and cheese sections with European delicacies. I paid for my provisions and then asked permission from the supervisor to borrow the shopping cart momentarily to wheel the groceries across the street to my hotel.

"No."

"Sorry, maybe you misunderstood. It is just for five minutes, just directly across the street there."

"No."

"I'll bring it back right away..."

"No."

Chagrined and annoyed, I left most of my bags on the cement patio in front of the store while I sweated three trips back and forth across the street. The market supervisor stood in the doorway and watched to make sure I didn't try to sneak the cart when he wasn't looking. ${ }^{2}$

\section{Honey}

That first evening in Jesudi, my hosts graciously showed me the lean-to they were providing for my shelter. My hammock fit nicely between the poles that supported the raw-hewn plank walls, and a blackboard that had seen better days served as a low door to block small animals from entry. My hosts Ei and Ijaoi, the leaders of Jesudi, loaned me a footlocker chest in which to store my things. As I unloaded my backpack, all their extended family crowded into the tiny space to watch, comfortably squatting or sitting on the dirt floor with me. I put my few items of clothes, plant press paraphernalia, and notebooks into the chest, along with some snacks-chocolate bars, granola, beef jerky, dried fruit and lemonade powder-that I hoped would keep me from getting too hungry in the weeks to follow. I felt self-conscious about sequestering food so I attempted to hide these edibles under other things as I transferred them; I'm sure my hostess $\mathrm{Ei}$ and the others noticed every last item nonetheless. I handed all the bulk foods over to Ei, as head of household, as a contribution to the family meals: cans of corned beef, large bags of egg noodle pasta, beans, oatmeal, carrots, onions, stew meat, five kilos of yerba mate, sugar, flour, and cooking oil. And the two-liter jar of supermarket honey. At the sight of the honey, an excited buzz started up among the children, and one was sent to fetch a big mixing bowl and a pitcher of water. I watched, intrigued, as Ei poured half of the honey into the bowl, mixed in a generous amount of water, and passed it back to me. I wasn't sure exactly what to do but took a sip from the honey-water drink-it was delicious-and passed the 
bowl to one of the children, who drank deeply. It went around the assembled group, each adult and child drinking until the sweet liquor was gone. Then Ei repeated the procedure with the remaining honey, emptying the two-liter jar completely, to the contented sounds of licked lips and sweetened sighs, and everyone went off to bed.

That, on my first night in Jesudi, was my second lesson in food protocols among people who grew up hunting, gathering, fishing, and gardening in the forests and palm savannahs of North-east Paraguay. If the first lesson, that of the anteater, was that all hunted meat will be carefully curated and shared out along prescribed relational rules, this second lesson was that if a boon resource is found, gather your people and consume it all, right then and there. Carry it away in the belly and the bloodstream rather than mess around with trying to transfer the sticky, runny stuff into containers and trying to store it in the relentless, fermenting heat of the Chaco. I had, of course, read about the first lesson especially, in ethnographies about other hunting societies, so the structure of the gifting was familiar when I saw it, a thrill of recognition running through me. But the feel of it as a social being was altogether new and unexpected. To feel the electric moment as a new social tie came into being, a strip of roasted meat passed from José Ikebi's hand to mine, an inauguration of reciprocities to come, and of being overtly included in a clear social web, was felt in the flesh more than understood by the mind.

The second lesson, the honey lesson, was more thoroughly illustrated to me a few weeks later, when Luis Ijaoi, the leader of Jesudi and the father of the extended group that was my host family, came home one day and reported that he had found a hollow tree full of bees. Again, the children buzzed with excitement, I was invited, and, gathering up all available receptacles-plastic soda bottles, buckets, and enameled bowls - we set off with him at a walk-jog to collect honey. Along the way through dense thicketed forest, he pointed out a dochiya'c tree (no Linnaean identification), leaning at a slight angle, that had been incised across its bark and living tissue at head height, in such as way so as to drip sap-water drawn up from its roots. Ijaoi explained that his people liked to create these water sources throughout their territories as a reserve in case of need, and if they were in use, they would place a container underneath to catch and store the filtered water that dripped from the tree after a rain. The container was usually a barrel made from the naturally-hollow trunk of a young cucoi (Chorisia insignis), placed on logs so as not to decay in contact with the earth.

A short ways on, we found the beehive. I approached cautiously, thinking of the vituperative ire of a disturbed hive. But the children ran right up to the tree in question, poked their fingers into its hollows, and pulled bark away where they could. All I had known until that point was that we were after honey, though I'm sure Ei and the others tried to explain to me that it was an ajidábia nest (a small, native, edible stingless species of black melipone bee [Melipona sp.]), my Ayoreode vocabulary did not yet include any of the numerous species of Chacoan honeybees. Ijaoi told his daughter and sons to stand back, and swiftly opened up the tree trunk with his axe. Layer upon layer of dark combs were exposed to sunlight, and dark liquid dripped amongst a cloud of tiny bees that had suddenly materialized. The children crowded in immediately, sitting back on their heels comfortably, as close as possible to the trunk, and proceeded to delicately pick out combs and put them into their mouths in rapid succession, as if intent on getting as much as possible as quickly as possible. Ijaoi and Ei looked on indulgently and collected handfuls for themselves, for me, and for the others in attendance. I followed the children's example and bit into the honeycomb's dark gold wax tunnels, larvae and allthe larvae were a delicacy - and was transported by an aromatic, flesh-tingling ultrasweet sensation. It was a new taste to me, having only eaten the various products of the reina, or European honeybee. This wild melipone honey was more delicate, nuanced, runny, and I imagined that it also tasted of the aromatic wood of its hive. Since then, I've heard Ayoreo people disparage the use of metal wires or frames in beekeeping, saying that it ruins the flavor of the honey. For quite a while, no one said anything. We just squatted there under the trees, gently waving away the mildly buzzing bees whose lifework we had just destroyed, eating, sucking, savoring, swallowing honey and bees, and spitting out tooth-marked balls of wax. I felt the sweet excess coursing through my arteries and capillaries, almost painful as it made its way to the surfaces of my skin. Perhaps we became a bit torpid, the excitement of the find transmuted into an altered state of sugary satiation, the gaze of the honey eater steady and even, everything slowed down around us, no thoughts to turn into words, just the obvious and shared pleasure in the abundance of deliciousness. 
Once we had regained a bit of focus, we filled the vessels we'd brought with the rest of the honeycomb, and carried them on the long return walk to Jesudi. It was clear to me that the efficiency of taking people to the spot to eat their fill then and there made good sense in this world.

\section{Hunger}

One of the recurrent topics of conversation in Jesudi, both in 1998 and in later visits, revolved around the lives and livelihoods of relatives-Totobiegosoode family groups, mostly-who still live in voluntary isolation en el monte (in the forest). While I was there in 1998, several incidents of controversial contact between ranch workers and silvicola (forest-dwelling) Ayoreo people occurred (see Besirre 2005, 2014). Young and old Jesudi residents were intensely intrigued and concerned with the plight of their relatives who were (and many still are) on the run: some advocated 'bringing them out,' others supported legal protection of their traditional territories so they could stay there indefinitely. With an empathetic genius for imagining what their lives might be like, which, for many, was also a remembering of similar personal experience when they were younger, people often commented on how hungry they must be, and what it must be like for the Totobiegosoode en el monte as they seek and prepare wild foods nowadays. One example in particular illustrates a sensorial awareness of the dimensions of interaction implicated by food practices that were veiled to me, having never experienced prolonged hiding from enemies. In 1998, knowing of my interest in wild foods, Ei graciously agreed to teach me how to collect and prepare doidie, a common spiny ground cover bromeliad (Bromelia balansae). It is time-consuming compared to the yield, so for the most part families no longer prepare this food in Jesudi, but report that it was a common food in the past. With machete-tipped ironwood digging sticks we cut, tied, and carried the wiry rosettes to a clearing, where we piled them several feet high over kindling and set them on fire. Ei was much more efficient at this work than I. An intense white smoke soon issued from the roasting pile, and the plants crackled and popped loudly as the leaves burned off (Figure 1). We sat nearby, waiting for the fire to die down so we could rake the roasted petiole bases out of the coals. Ei watched and listened, and soberly commented that though this was a predominant food source for people living in the forest, the Totobiegosoode would not feel safe cooking it any longer, because as a food doidie was too noisy. The sharp popping and crackling, and the white smoke could give their location away to outsiders, whom would all be perceived as dangerous, mortal enemies.

Each morning, the two daily eggs from the (notvery-productive) family hens were cracked into a pot of canola oil boiling over a wood fire. The whites frothed up into a feathery nest around quickly hardening yolks, and each was scooped out with a spoon and deposited on a plastic dish and cut into small pieces for the children to eat. I watched, interested because I had never seen a deep-fried egg before, but also recognizing in myself a hunger I hadn't often experienced. Of course I had been plain old peckish many times, but this was a deeper, sharper, more specific hunger, likely for protein, which, while in Jesudi, had been lacking from my diet for several weeks. I watched the three kids eat the two eggs, sharing them equally, and I was immensely glad that they were getting this protein, at the same time that I averted my eyes, trying to mask my interest so as not to make them uncomfortable. I also craved greens, fruits, and vegetables during the weeks I was in Jesudi. We gathered wild foods but usually only enough to taste, not eat our fill. We had lots of delicious squash, which was stored on the vine in the fields it had grown in, protected from the frost under piles of dried grass. Curiously, however, leafy greens of any kind did not seem to be a part of the Ayoreo diet, though Chenopodium and other weedy edibles grow prolifically in Jesudi. There was a lettuce farm some kilometers down the road that sent its produce to market weekly, and when I could I did my best to waylay the trucks and buy some from the drivers.

One of the narratives that adults return to regularly was their worry that there won't be enough to eat for themselves or the children in Jesudi. In 1998 the community was somewhat dependent on getting deliveries of gift food from the Red Cross, UNICEF, or other aid and government organizations. By settling in Jesudi as an independent community, these families were experimenting with a life in-between the lifestyle most of the adults had grown up in (hunting, gathering, fishing and growing foods in el monte) and the life they led as dependents employed on Mennonite farms or in the mission camps, with limited access to forest foods and land to move around on. In Jesudi people had more freedom and autonomy to organize their own life projects; "to seek out foods and benefits for their families" (Picanerai 2011), but the 5,000 hectares 


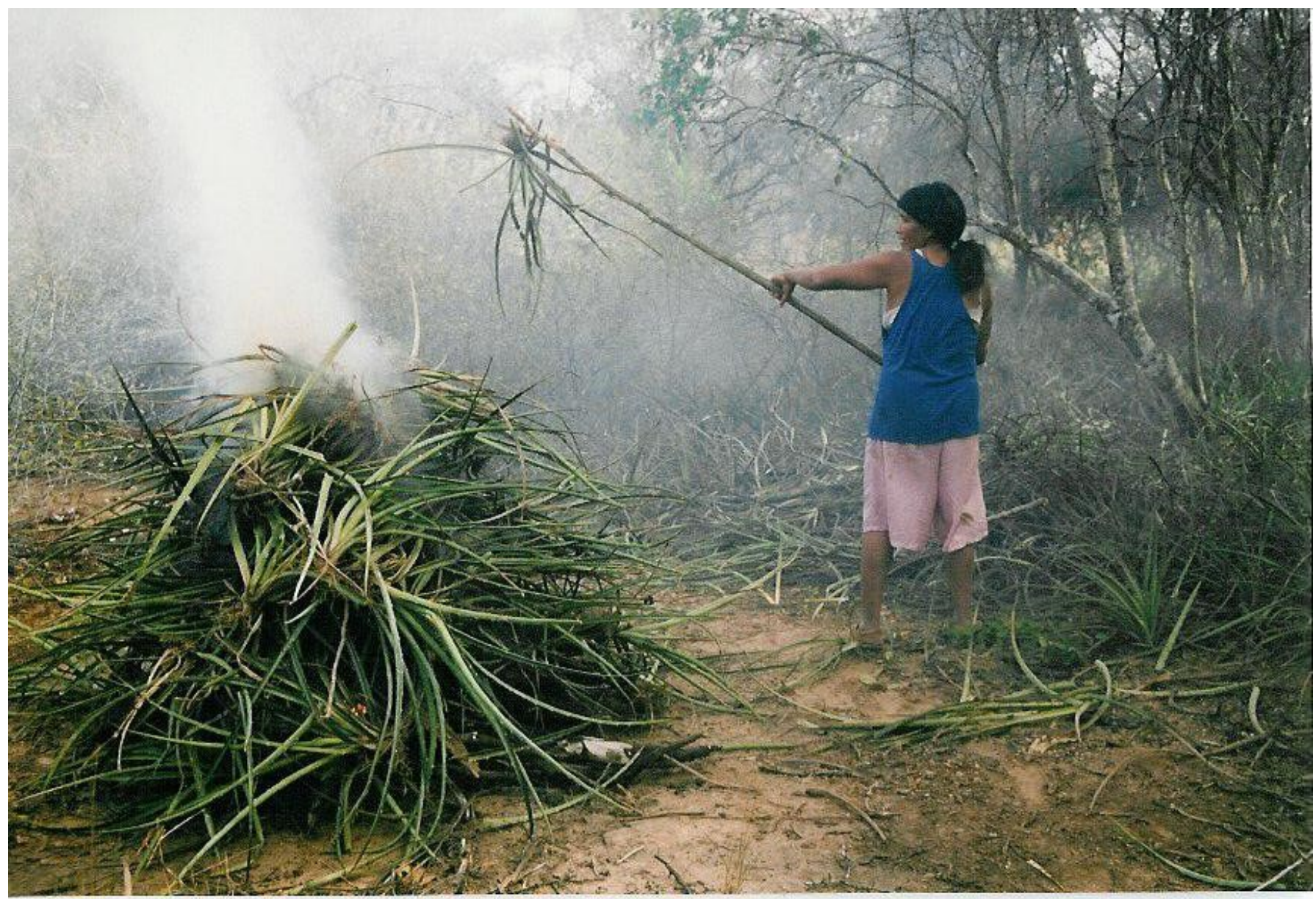

Figure 1 Ei Posinho burning a pile of doídie bromeliads, 1998, by the author.

of Jesudi lands wasn't necessarily enough land, or the right ecotype, to reproduce their former livelihoods en el monte.

The more I paid attention to what the children were doing moment-to-moment as they went through their days I noticed that they took every opportunity to eat a diverse array of foodstuffs. No matter how minor the resource seemed to me, to them it was fun, a game, a challenge, a shared activity, or just an opportunity to satiate a passing hunger. They picked nectary flower blossoms to share amongst themselves, and made tiny fires on which they cooked tiny stews in tuna-fish cans. When the men cut, stacked and hauled palo santo (Bulnesia sarmientor) logs on a truck to take to town, children would snap slender twigs from nearby bushes and poke these into holes in the exposed cross-sectioned logs, drawing them out carefully and sliding them through their lips to get the droplets of wild honey that solitary bees had deposited in the trunks of these aromatic trees (Figure 2).
The logs were destined to be sold in Filadelfia, which at that time still ran its electricity plant by burning endemic Chacoan ironwood trees. When someone went to town to sell the logs, they'd bring back treats for the kids in the form of a ziplock bag of Hellman's mayonnaise and a brown sugarloaf, and they would sip and nibble in turn on one, then the other, until they were gone.

\section{Free for All: Mattresses and Lollipops All Around}

One day in Jesudi, as we women were relaxing in the shade on our sitting cloths, twining bromeliad string with white ash on our thighs, those around me suddenly lifted their heads to listen. I could hear nothing new. "Camión Cruz Roja!" one woman cried and everyone immediately set aside their things and started running towards the driveway entrance to Jesudi, some 600 yards away. They kept shouting to the others as they ran, and people appeared out of their houses and joined in the sprint. I followed, and 


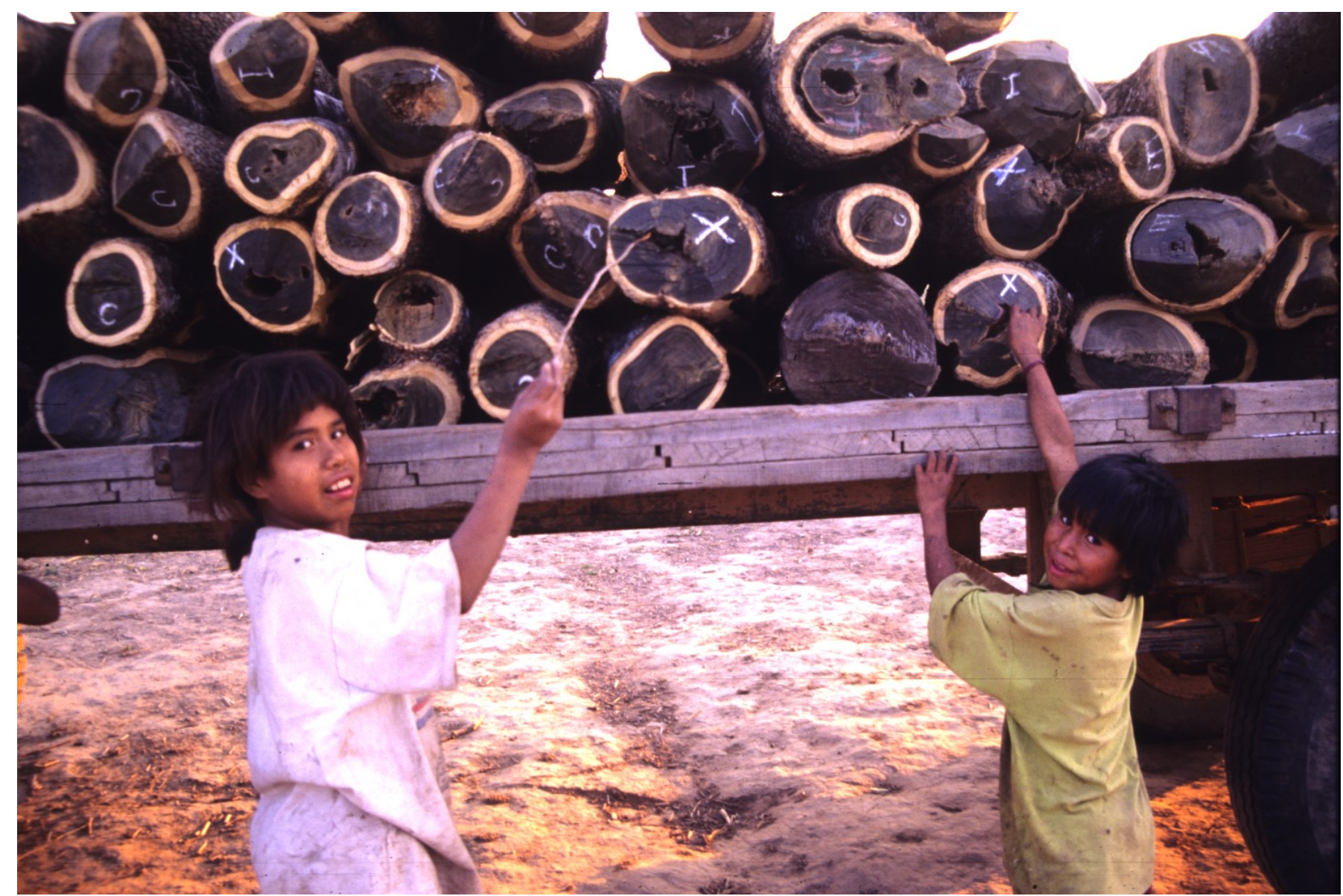

Figure 2 Sampling honey treats from bee-tunnels in palo santo logs on a truck bound for market, 1998, by the author.

by the time I got there, a crowd had gathered, and I could just make out the growl of a truck's engine coming towards us on the red dirt road. It slowed, and turned onto the Jesudi entrance track. As soon as it stopped, people surrounded it. The men in the cab got out, greeted the Jesudi leaders, and then climbed into the bed of the truck and started to throw out a flurry of plastic-wrapped mattresses, blankets, gunnysacks of pasta, and jugs of peanut oil, each item grabbed by the first person in the crowd to touch it. I was stunned by the rapidity and the chaos of the handout-so different from the carefully considered distribution of the meat from a single anteater amongst the group a couple weeks earlier. As far as I could tell, it was a free-for-all, and those who grabbed an item first got to keep it for their family. As soon as their truck bed was empty, the Red Cross workers jumped back into the cab, made a tight u-turn, and drove off, heading to the next community.

A few days later, another truck arrived, also identified by the unique sound of its engine by those around me long before I could hear it. This one brought a health NGO team, who interviewed the residents of Jesudi, and distributed some food, including an enormous bag of lollipops for the children, which they gave to one of the moms to hand out. Clearly used to this process, the children, about 23 of them, immediately formed a queue, from youngest to oldest, and each was handed one lollipop. Upon receiving it, the child went right back to the end of the line, and each got a second candy. After every child had received three lollipops, there were some left over, but not enough for everyone to get a fourth. Again with no hesitation, deliberation, or instructions, the five youngest children, mostly three- and four-year -olds, took the remaining lollipops over to a nearby flat tree stump, gently smashed them with a hammer, and then divided the candy powder into five equal piles and proceeded to each consume their pile of sweet dust by pressing and licking their fingers (Figure $3)$.

The rules of food and resource distribution 


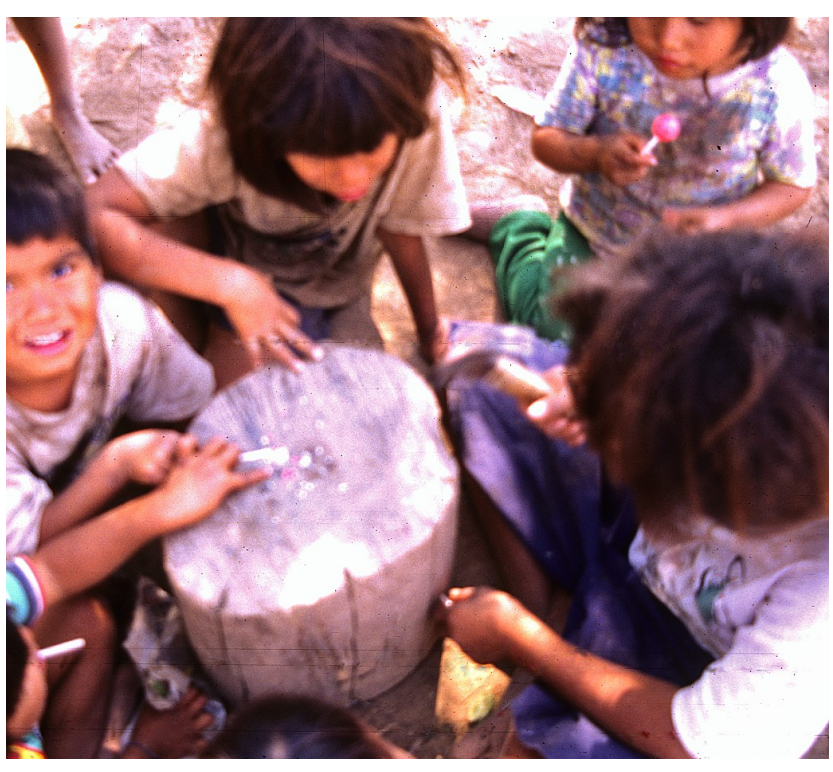

Figure 3 Jesudi children in charge of equitably dividing up an odd-number of lollipops amongst themselves, 1998, by the author.

became a bit clearer to me when, much later, I was working on a forthcoming book based on Ei Posinho's life story, and she explained in detail the moral code that dictates that the smallest children should always be fed first, with special foods 'reserved' for them so they can eat even in times when the rest of the family goes hungry. She also related her sister Puúa's account from the time in el monte (meaning before their transition to living among Paraguayans), which shed some light on the claiming of resources in a world that is otherwise free for all. Puúa and several other women had been on a foodgathering trip when in the near distance they spied a grove of prized edauóde palm trees-a species that yields abundant edible flour from its trunk (probably Syagrus romanzoffiana). Puúa recognized an especially mature tree, sure to provide a great deal of food, by its dark horizontal stripes and sprinted towards it to claim it for herself and her family. But another woman sprinted toward it at the same time, and though Puúa thought that she had definitely touched and claimed it first, the other woman argued loudly, saying that it should be hers, fighting until she got her way. For years this memory had rankled with Puúa's sense of fair play and she used it as a teaching anecdote to instruct her sister $\mathrm{Ei}$ in proper food rules. For certain items, such as palm trees and Red Cross blankets, the first person to touch it gets to keep it. Lollipops and giant anteater meat, on the other hand, should be carefully apportioned according to social ties and standing in one's immediate group. The difference likely has to do with whether or not the item is 'windfall,' that is, still in a wild state of noclaim, in which case it is up for grabs... and then, once a claiming has occurred, the social sharing rules kick in so that the item is distributed and credit, prestige, and reciprocal obligation circulate.

A frequent comment Jesudi residents made about the transition from forest life to mission life was how surprised they were to discover that outside of el monte all foods, especially plant foods, were not free. Not only was the landscape itself carved up into owned pieces, but all the foods growing upon it also had owners. For Ayoreo individuals who first came in contact with cojnone in the $60 \mathrm{~s}, 70 \mathrm{~s}$, and $80 \mathrm{~s}$, and still today, food transactions are the most ubiquitous quotidian economic interface with non-Ayoreo peoples, and are thus also inherently linked to political and ideological difference. Gifts of food were, and still are, used by missionaries to attract people to attend church services. People still talk about the moment when they realized, after accommodating to mission camp life and the horrors of their transition from forest to settlement, that the foodstuffs they had been given by the cojñone were not always gifts, but came with obligations of physical labor and other services, including sex services. Though most of the food of the cojnone was unpalatable3 to the recently arrived, they soon discovered that a key aspect of their loss of autonomy related to their inability to harvest foods for their own families, on their own terms.

Gifts of food were, and still are, used by anthropologists to initiate and continue relationships of teaching and learning with local communities. I brought foodstuffs with me as gifts in 1998, and I still take lots of extra food with me when I visit Jesudi, as a contribution to the material sustenance of the families who host me, and as a way to reciprocate for their time and any inconvenience of my presence, aside from any research-related compensations. As I have investigated the personal histories of coercion, obligation, and exploitation experienced by Ayoreo groups of the last hundred years, however, my awareness of the imbalances involved has become ever more acute. Though it is a complex history, the basic relations are simple: their means of production have been coopted by ours. Their homelands have been grabbed by the state, by settlers, and by multinational corporations, bulldozed, planted in buffel 
grass pasture, and populated with beef grow-lots. The foods of the Chaco are now exported to supermarkets around the world in the form of dairy and beef products. These are the macro-structural relations of food in this place. The micro-structural relations of daily interaction for the Ayoreo continue in the sections of landscape that have not been coopted by outsiders: children learning to automatically share sweets amongst themselves, the now rare game-meats lauded and carefully distributed, the jockeying for gifts/grants from outside projects, and selling one's labor to the cattle ranchers.

\section{Conclusion}

The Chaco as a productive foodscape is in the process of transforming. Transforming from a place where resources were diverse, and literally free for all who lived there, into a place that has been more of a free-for-all of non-indigenous settler resource appropriation via ideology, law, and firepower. There is quite a bit of space, in Ermine's sense, between the worldviews of the indigenous peoples and those of the settlers. People from each community feel that their way of relating to the landscape is correct and natural. By being there in person, forging individual relationships with Ayoreo community members, learning from their stories and, perhaps most of all, experiencing the electricity of inclusion in the form and reason of food sharing, one begins to learn to see the spaces between those worldviews, and the spaces between the material worlds we create by our actions.

\section{Notes}

"We always eat together when she gets food." This recommendation from a young Ayoreo girl was one of several messages tape-recorded about me by Jesudi community members upon my departure from the Chaco in 1998, meant as a report or assessment for my supervisors and parents. I later learned more explicitly that whether or not a person shares food with children is a key test of character in Ayoreo ethics.

${ }^{2} \mathrm{Of}$ course, this may have been my paranoid interpretation. He may have been watching my groceries to make sure no one took them while I made the trips back and forth across the street. Since this unfriendly first encounter, I have met many other Filadelfians and members of the Mennonite communities elsewhere who were extremely helpful, welcoming, and generous.

${ }^{3}$ Many reports from this time concur that rice, sugar, bread, wheat, and other foods of the cojñone were perceived as smelling and tasting horrible to the Ayoreo, especially to the elders. It is not uncommon to hear of elders who starved to death rather than eat the new foods (which were also associated with extreme cultural and social trauma), and of the efforts by their family members to find wild and traditional foods for them. Sweet potatoes, watermelon, and squash were foods common to both the Ayoreo and cojñone communities but only seasonally available.

\section{Acknowledgements}

This work was made possible by Ei Posinho, Ijaoi Dosapei and their family, all the residents of Jesudi, and Justina Taobi Juuminé's translations. Thanks also to Ted Gragson, who made me aware of Jesudi in 1998; Antonia Barreau-Daly, who assisted with research in 2011, the many people in Paraguay who generously gave of their time along the way, two anonymous reviewers and editors Mac Marston and Rick Stepp.

\section{Declarations}

Permissions: Institutional Review Board and Behavioral Research Ethics Board permits for research were obtained from the University of Georgia (1998) and the University of British Columbia (2011-12), respectively. Permissions were granted by Ayoreo community members after informed consent conversations took place during each research visit.

Sources of Funding: National Science Foundation ethnographic research training grant (1998), and Social Science and Humanities Research Canada standard research grant (2011-2012).

Conflicts of Interest: None declared.

\section{References Cited}

Bessire, L. 2005. Isolated Ayoreo: Will History Repeat Itself in the Gran Chaco? Before Farming 2:1-4. DOI:10.3828/bfarm.2005.2.1.

Bessire, L. 2014. Behold the Black Caiman: A Chronicle of Ayoreo Life. The University of Chicago Press, Chicago, IL.

Blaser, M. 2010. Storytelling Globalization from the Chaco and Beyond. Duke University Press, Durham, NC.

Ermine, W. 2007. The Ethical Space of Engagement. Indigenous Law Journal 6:193-203.

Glauser, B. 2011. Being Indigenous: The Concept of Indigeneity, a Conversation with Two Ayoreo Leaders. In The Politics of Indigeneity: Dialogues and 
Reflections on Indigenous Activism, edited by S. Venkateswar and E. Hughes, pp. 21-44. Zed Books, London.

Mauss, M. 1990 (1950). The Gift: The Form and Reason for Exchange in Archaic Societies. Routledge, London.

\section{Special Issue on Memoirs and Memory}

Picanerai, A. 2011. Online audio interview on the work of the Unión de Nativos Ayoreos de Paraguay. Available at: www.iniciativaamotocodie.org/unap/ files/entrevista_aquino-picanerai.mp3. Accessed on $3 / 20 / 2011$. 